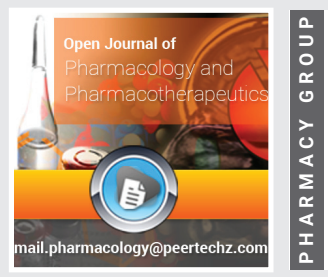

\section{Variable epitope library-based COVID-19 vaccine for current and future related epidemics}

\author{
Karen Manoutcharian*, Jesus Guzman Valle1 and Josué \\ Odales \\ Instituto de Investigaciones Biomédicas, Universidad Nacional Autónoma de México (UNAM), \\ Apartado Postal 70228, Cuidad Universitaria, CDMX, CP 04510, México
}

Received: 18 March, 2020

Accepted: 06 April, 2020

Published: 07 April, 2020

*Corresponding author: Karen Manoutcharian, Instituto de Investigaciones Biomédicas, Universidad Nacional Autónoma de México (UNAM), Apartado Postal 70228, Cuidad Universitaria, CDMX, CP 04510, México, E-mail: karman@unam.mx

Keywords: Variable epitope libraries; SARS-CoV-2, COVID-19, Vaccine; Antigenically variable pathogens https://www.peertechz.com

Check for updates
The outbreak of yet another epidemic (now COVID-19 pandemic) caused by SARS-CoV-2, has reminded the scientific community and, more importantly, the world that in spite of all the financial and human resource investment in vaccine development against major diseases, the success rate has not been satisfactory. Accordingly, we must take extraordinary measures to try and contain the spread of this disease and find efficacious treatment options; the generation of prophylactic/ therapeutic vaccines may resolve these objectives. COVID-19, amongst other diseases, are major public health concerns, which up to now, have remained difficult to deal with; of course we are not simply referring to the most recent epidemic(s) but of others as well, even the one that started it all, HIV/AIDS. These diseases (HIV, Influenza, Zika, Dengue, Malaria, HCV, etc.) are caused by what we have called antigenically variable pathogens (AVPs) [1]. The generation of vaccines against any member of this group represents a formidable challenge, but the hurdles are similar. Our vision is that these "impossible" diseases are similar at one basic and fundamental level: Genomic and antigenic instability. This overwhelming feature has discouraged many, however, sanguine researchers have attempted more traditional approaches (whole-pathogenor cell-based vaccines), while others have steered towards reductionist thinking of biological-immunological events via structure-based reverse vaccinology methods. Overwhelming scientific evidence obtained from decades-long attempts have shown that traditional and "novel" approaches in vaccine design against AVPs have failed on multiple occasions (HIV being the prime example). This has been confirmed by the maximum criteria for the efficacy of vaccines, which are phase 3 clinical trials. We can state that one probable reason for failure is that past and present vaccine generation platforms are not addressing the major issue of genetic/antigenic variability, and therefore, the use of defined antigen sequence immunogens (DASIs) will induce immune responses that will lag with respect to the pathogen's mutational rate. Therefore, there is no reasonable argument for why we should expect positive outcomes pursuing these approaches in vaccine design, backed by a plethora of previous failed attempts.

The vaccine concept we have developed is termed Variable Epitope Libraries (VELs), these are artificial combinatorial libraries of heavily mutated epitopes derived from pathogen protein sequences. The primary objective of VELs is to activate the largest possible CD8 + T cell repertoire. The efficacy of VELs has been proved in our previous studies: an HIV-1 antigenbased VEL induced HIV-1 neutralizing serum (neutralization of half of a tier 2 panel of primary HIV isolates) [2]; and in a murine breast tumor model, VELs were able to inhibit aggressive breast cancer in terms of tumor growth [3] and metastasis [4]. Our results are best-in-class achievements in their corresponding fields. The advantages of VELs, first and foremost, is their universal application, but also, they can be used with any pharmaceutically acceptable carrier and delivery systems: DNA, mRNA, viral vectors or nanostructures, DCbased vaccines, or others.

Predictions on how the pandemic will evolve are varied but most are pessimistic and have offered no defined resolution. Different treatment options have been used, including nontraditional approaches, leading to empirical clinical data that has helped many. However, a consensus has been reached by scientific researchers in academia, as well as in private organizations, that the best way to contain this disease is by the development and use of a vaccine(s). In light of this, and with the intention of contributing, as has the world scientific 
community, our team designed and generated VEL-based vaccines against SARS-CoV-2. Multi-epitope regions were selected and identified from reported sequences [5] of the virus using in silico methods covering major protein sequences of SARS-CoV-2. The newly generated vaccines, named CorVac-19/20, consist of a panel of 11 possible candidates for future vaccines, each bearing a VEL carrying from thousands to millions of mutated epitopes. These could be used in both prophylactic and therapeutic settings, however, preclinical models are required in order to advance to human trials. A striking feature of CorVac-19/20 is that these vaccines resemble, not only, the antigenic diversity (evidenced in almost 600 genomes sampled) of the 10 currently circulating SARSCoV-2 viral clades [6], but may also target future mutated versions, since the VELs activate the largest possible repertoire of CD8+ T cells, and importantly, could generate a similar subpopulation of memory cells. In other words, immunization with CorVac-19/20 may prevent future disease from similar viruses. We are convinced that the application of CorVac-19/20 in pre or clinical trials in parallel with conventional vaccines or alone is justified and promising.

We have used the daunting feature of antigenic variability as a method to counterattack COVID-19, which has shown widespread mutations. We have looked beyond the genome and created a new vaccine platform which reflects the same feature as these diseases: antigenic variability. Strikingly, if we consider that during infection with AVPs (as well as in cancer) the evolving mutational landscape interferes with protective natural immune responses, then, we have gone one step further and administered simultaneously a massive number of mutated antigens. We are compressing the time in which the human body could possibly face this unprecedented amount of pathogen-based mutated antigens. We believe that common problems (AVPs) require common solutions (VELs). While our approach is seemingly "unreasonable" and even unusual, it is the only current vaccine approach that directly addresses antigenic variability. Currently, no approved vaccines exist to prevent or treat infection with SARS-CoV-2 but a Phase 1 clinical trial evaluating an investigational vaccine designed to protect against COVID-19 has recently begun (ClinicalTrials. gov Identifier: NCT04283461). In spite of this, we feel that the use of DASIs, in whatever format they may be presented, will not offer adequate protection due to the fact that the issue of antigenic variability is not being addressed for the evolving pathogen.

\section{References}

1. Servín-Blanco R, Zamora-Alvarado R, Gevorkian G, Manoutcharian K (2016) Antigenic variability: Obstacles on the road to vaccines against traditionally difficult targets. Hum. Vaccines Immunother 12: 2640-2648. Link: https://bit.ly/2RiixZN

2. Charles-Niño C, Pedroza-Roldan C, Viveros M, Gevorkian G, Manoutcharian K (2011) Variable epitope libraries: New vaccine immunogens capable of inducing broad human immunodeficiency virus type 1-neutralizing antibody response. Vaccine 29: 5313-5321. Link: https://bit.ly/2JGOTcy

3. NoeDominguez-Romero A (2014) Variable epitope library carrying heavily mutated survivin-derived CTL epitope variants as a new class of efficient vaccine immunogen tested in a mouse model of breast cancer. Hum. Vaccines Immunother 10: 3201-3213. Link: https://bit.ly/2JHLtpR

4. Servín-Blanco R (2018) Generation of cancer vaccine immunogens derived from major histocompatibility complex (MHC) class I molecules using variable epitope libraries. Immunol. Lett 204: 47-54. Link: https://bit.ly/2UN05dV

5. Johnson M (2020) Wuhan 2019 Novel Coronavirus-SARS-CoV-2. Mater Methods 10: 2867. Link: https://bit.ly/2V5AUm4

6. Hadfield (2018) Nextstrain: Real-time tracking of pathogen evolution Bioinformatics. 34: 4121-4123. Link: https://bit.ly/3e0AuG9
Discover a bigger Impact and Visibility of your article publication with

Peertechz Publications
Highlights

* Signatory publisher of ORCID

* Signatory Publisher of DORA (San Francisco Declaration on Research Assessment)

- Articles archived in worlds' renowned service providers such as Portico, CNKI, AGRIS, TDNet, Base (Bielefeld University Library), CrossRef, Scilit, J-Gate etc.

* Journals indexed in ICMJE, SHERPA/ROMEO, Google Scholar etc.

* OAI-PMH (Open Archives Initiative Protocol for Metadata Harvesting)

- Dedicated Editorial Board for every journal

Accurate and rapid peer-review process

Increased citations of published articles through promotions

Reduced timeline for article publication

submit your articles and experience a new surge in publication services (https://www.peertechz.com/submission).

Copyright: (C) 2020 Manoutcharian K, et al. This is an open-access article distributed under the terms of the Creative Commons Attribution License, which permits unrestricted use, distribution, and r eproduction in any medium, provided the original author and source are credited.

Citation: Manoutcharian K, Valle JG, Odales J (2020) Variable epitope library-based COVID-19 vaccine for current and future related epidemics. Open J Pharmacol Pharmacother 5(1): 007-008. DOI: https://dx.doi.org/10.17352/ojpp.000011 